\title{
STUDY OF INCOME COMPARISON ON POTATO FARMERS BETWEEN PANENMART'S PARTNER AND NON-PARTNER \\ ${ }^{*} 1$ Amran, Farizah Dhaifina, ${ }^{2}$ Husain, Tsalis Kurniawan \& ${ }^{3}$ Amri, Andi Azrarul
}

${ }^{* 1}$ Universitas Muslim Indonesia, Department of Agribusiness, Faculty of Agriculture, Makassar, Indonesia
2 Universitas Muslim Indonesia, Department of Agribusiness, Faculty of Agriculture, Makassar, Indonesia
${ }^{3}$ Universitas Muslim Indonesia, Department of Agribusiness, Faculty of Agriculture, Makassar, Indonesia

\begin{tabular}{l}
\hline ARTICLE DETAILS \\
\hline Article History \\
Published Online: \\
JIAE (Journal Indonesian Applied \\
Economic) \\
\hline Keywords \\
Potato Farmers, Panenmart, \\
Partners, Income \\
\hline
\end{tabular}

"Corresponding Author

Email: farizah.dhaifina@umi.ac.id

\begin{abstract}
The supply chain has become a problem in the trade of agricultural products. The farmers still got low prices while the price at the end consumer is high. Panenmart is there to help improve the welfare of farmers, especially horticultural farmers in South Sulawesi by establishing appropriate food prices and sustainable supply. The objectives of this study are: 1) To identify the factors that determine the decisions of potato farmers in Kanreapia Village, Gowa Regency in partnering with Panenmart. 2) To analyze income differences between potato farmers in Kanreapia Village, Gowa Regency in partnering with Panenmart. The research was carried out in Kanreapia Village, Gowa Regency because it is a vegetable producing region with several farmers partnering with Panenmart. The number of respondents used was 40 people, which are 20 Panenmart's farmers partner and 20 of the nonpartner. The results found that 1 ) The factors that determine the decision of potato farmers in Kanreapia Village to partner with Panenmart are the age and the farmers' institution. 2) There is no significant difference in income between both groups.
\end{abstract}

\section{Introduction}

One of a problem that already exist since long time ago in agricultural trade is the long supply chain that must be passed from producers (farmers) to consumers. The high price benefit of vegetables and fruit at the consumer level can sometimes not be obtained by farmers as producers. Farmers cannot get results from these high prices because the middlemen usually get a larger margin and the market information is usually hidden by them. This problem has been around for a long time and has not seemed resolved until now. The long distribution chain is actually not a problem as long as farmers could get a fair price.

Established in 2016, Panenmart to help improve the welfare of farmers, especially horticultural farmers in South Sulawesi. Panenmart was built as a social enterprise that develops technology solutions and information systems, especially for farmers and the people of Indonesia. Through a mobile-based application, Panenmart strives to provide online raw food product trading solutions in order to achieve food price stability by shortening the supply chain from farmers to the end consumers and helping farmers to increase their access to the market so farmers as producers could get a fair position and consumers can enjoy fresh food directly from farmers. Panenmart's vision is to realize a more equitable distribution of food production and consumption by establishing appropriate food prices and sustainable supplies.

At first not many farmers were willing to partner with Panenmart because especially for older farmers who were already got tied debt with middlemen as debt collectors. In addition, farmers are also reluctant to partner because they need cash and do not want to be paid back so slowly Panenmart follows the rules in the market. After nearly three years in the business, Panenmart has not received a significant increase in the number of farmers who are willing to become Panenmart partners. This problem is complicated because the role of the mafia in the farmer environment is also difficult to overcome and Panenmart does not have the strength to deal with them. Because Panenmart has not been able to strengthen its position in the field, Panenmart is now still focused on strengthening market place at the consumer level.

Partnership has an important role for farmers, namely as a distribution of production facilities, sales of products, capital supply, farming development programs, and 
improvement of input and output prices. The partnership is expected to be able to provide beneficial effects for partner farmers such as increased income which will have an impact on improving the welfare and standard of living of farmers (Cahyarubin, 2016). Several vegetable farmers from various villages in South Sulawesi have become active partners of Panenmart. The village with the most participating farmers is in Kanreapia Village, Gowa Regency. But there are still farmers who have not been interested to participate. This is suspected by the speed of adoption or the level of adoption that varies in each individual farmer. Therefore, this study intends to examine the formulation of the problem is as follows: 1) To identify the factors that determine the decisions of potato farmers in Kanreapia Village, Gowa Regency in partnering with Panenmart. 2) To analyze income differences between potato farmers in Kanreapia Village, Gowa Regency in partnering with Panenmart. The research was carried out in Kanreapia Village, Gowa Regency because it is a vegetable producing region with several farmers partnering with Panenmart.

The study was conducted in Kanreapia Village, Gowa Regency which is one of the potato producers in the province. There were 40 potato farmers interviewed as the respondents, which 20 of them are Panenmart's farmers partner and the rest 20 are non-partner.

To assess the first objective, multiple logistic regression was used. The multiple logistic regression model is a logistic regression model with more than 1 predictor. In multiple logistic regression, the researcher predicts the dependent variable that has a dichotomy scale. The dichotomy scale in question is a nominal data scale with two categories, for example: Yes and No, Good and Bad or High and Low (Harlan, 2018).

To assess the second objective, independent sample t-test method was used. TTest is conducted to compare the average of two groups/ populations that are not related to each other, whether the two groups/ populations have the same average or not significantly (Saifuddin, et al., 2009). In this study the two populations to be compared are partner farmers and nonpartner farmers, the average value to be tested is the average value of income of each population.

\section{Results and Discussions}

A. Description of Panenmart Partnership with Potato Farmers in Kanreapia Village

Panenmart purchases fresh vegetables directly from farmers with the aim of ensuring

Faculty of Agriculture,

University of Muslim Indonesia product freshness and also to cut the long supply chains so that prices at the end consumer can be cheaper. The location of the purchase is spreaded in several areas in the province, one of them is in Kanreapia Village, Gowa Regency. However, for some products that cannot be obtained directly from the planting location, Panenmart purchases from the middlemen at Makassar City's largest traditional market in the early hours of the morning and has to compete with market retailers.

Since the beginning of 2020, Panenmart has been conducting Business to Business collaboration with a hotel in Makassar City. Panenmart acts as a supplier of potatoes at the hotel. The hotel has a high standard for potatoes: the tuber size must be large. The large potato tuber can only be obtained from the production in Kanreapia Village, Gowa Regency. Therefore, Panenmart has a partnership with farmers in the village since then.

Mr. Jamaluddin is a landowner but does not work on his own land acting as a contact person in partnership with Panenmart. Mr. Jamaluddin has the role of coordinating the harvesting of potatoes in accordance with Panenmart's request. After harvesting, the potatoes are sorted and only taken in large size and then prepared to be distributed directly to Panenmart. Mr. Jamaluddin and Panenmart set higher prices for farmers so farmers were more interested to sell their potatoes to Panenmart instead of selling them to middlemen at the village level.

The type of partnership run by Panenmart and the respondents are called general trade partnership. According to Hafsah (2000), the general trade partnership is a business relationship in the marketing of products. The party involved in this pattern is the marketing party with the commodity supplier group. Some horticultural farmers or farmer groups join in the form of cooperatives or other business entities and then partner with supermarkets or other business partners. The farmer cooperative is tasked with meeting the needs of supermarkets with specified requirements.

\section{B. Characteristics of Respondents}

The characteristics of the farmers describe their condition and status in farming. Characteristics of a respondent will be very helpful in the research process because it can provide information about the state of the farm, especially in terms of increased production. The characteristics of the respondent described below illustrate the diversity of respondents from several aspects including age, level of education, number of family dependents, 


\section{Study of Income Comparison on Potato Farmers between Panenmart's Partner and Non-Partner}

farming experience, land ownership status, and the total area of land they are working on. A summary of the distribution of sociodemographic characteristics of respondents in Kanreapia Village, Gowa Regency, which partners and does not partner with Panenmart is presented in the following table.

Table 1. Distribution of Partner and NonPartner Panenmart Farmers by Respondent Characteristics in Kanreapia Village, Gowa Regency, 2020.

\begin{tabular}{|c|c|c|c|c|}
\hline \multirow{2}{*}{ Variable } & \multicolumn{2}{|c|}{ Partner } & \multicolumn{2}{|c|}{ Non-partner } \\
\hline & $(n=20)$ & $(\%)$ & $(n=20)$ & (\%) \\
\hline \multicolumn{5}{|l|}{ Age (year) } \\
\hline \multirow{2}{*}{$20-32$} & 1 & 5 & & 1 \\
\hline & 0 & 0 & 2 & 0 \\
\hline \multirow{2}{*}{$33-45$} & 1 & 5 & 0 & 4 \\
\hline & 0 & 0 & $y$ & 5 \\
\hline $46-58$ & 0 & 0 & 9 & $\begin{array}{l}4 \\
5\end{array}$ \\
\hline \multicolumn{5}{|c|}{ Education Level } \\
\hline \multirow{2}{*}{ SD } & 1 & 5 & 1 & 6 \\
\hline & 0 & 0 & 2 & 0 \\
\hline SMP & 7 & $\begin{array}{l}3 \\
5\end{array}$ & 6 & $\begin{array}{l}3 \\
0\end{array}$ \\
\hline \multirow{2}{*}{ SMA } & & 1 & & 1 \\
\hline & 2 & 0 & 2 & 0 \\
\hline S1 & 1 & 5 & 0 & 0 \\
\hline \multicolumn{5}{|c|}{ Number of Family Dependents } \\
\hline \multirow{2}{*}{$1-2$} & 8 & 4 & 2 & 1 \\
\hline & 0 & 0 & 2 & 0 \\
\hline \multirow{2}{*}{$3-4$} & 1 & 5 & 1 & 7 \\
\hline & 1 & 5 & 5 & 5 \\
\hline $5-6$ & 1 & 5 & 3 & $\begin{array}{l}1 \\
5\end{array}$ \\
\hline \multicolumn{5}{|c|}{ Farming Experience (year) } \\
\hline \multirow{2}{*}{$7-19$} & 1 & 7 & & 2 \\
\hline & 5 & 5 & 5 & 5 \\
\hline \multirow{2}{*}{$20-32$} & 5 & 2 & 1 & 6 \\
\hline & 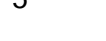 & 5 & 3 & 5 \\
\hline $33-45$ & 0 & 0 & 2 & 1 \\
\hline \multicolumn{5}{|c|}{ Total Area of Land (ha) } \\
\hline \multirow{2}{*}{$0,2-1,4$} & 1 & 7 & 1 & 9 \\
\hline & 5 & 5 & 9 & 5 \\
\hline $1,5-2,7$ & 4 & $\begin{array}{l}2 \\
0\end{array}$ & 1 & 5 \\
\hline $2,8-4,0$ & 1 & 5 & 0 & 0 \\
\hline \multicolumn{5}{|c|}{ Land ownership } \\
\hline Owner & 9 & $\begin{array}{l}5 \\
5\end{array}$ & 5 & $\begin{array}{l}2 \\
5\end{array}$ \\
\hline Sharecropp & 1 & 6 & 1 & 7 \\
\hline er & 1 & 5 & 5 & 5 \\
\hline
\end{tabular}

Table 1 shows the socio-demographic characteristics between respondents who are Panenmart partners and non-partners. Based on the table, there is no large difference in terms of the percentage of internal characteristics between partner and non-partner farmers. For further information, it can be seen in detail in the discussion of respondent characteristics below.

The majority of the respondents $(47.5 \%$ or 19 people) lies in the age group of $33-45$ years. The age condition of respondents indicates that they are at a productive age. Susanti, et al. (2016) said the productive age of farmers is between $30-59$ years. Farmers aged $30-59$ years have the physical potential to support farming activities, dynamic, creative, and fast in accepting new innovations. Whereas farmers who are above 59 years old have advantages in terms of experience, consideration, work ethics and commitment to quality. The weaknesses of farmers with 59 years above are often considered to be less flexible and reject new technology. Farmers who are classified as not young anymore tend to be difficult to accept new information and innovations. According to Soekartawi (1988), someone who has a young age tends to have enthusiasm and have a higher curiosity than people who are old (> 50 years). High enthusiasm and curiosity will encourage someone to learn and find information and try to do experiments. Furthermore, young farmers are still able to accept new innovations in increasing production from productive activities they do and have the greatest possibility to make the decision to do farming that can provide the greatest benefit.

The level of education of respondents in Kanreapia Village was relatively good because most farmers were able to receive compulsory education for 12 years. Education in the agricultural cultivation sector is still classified at the low level because the agricultural population in the village feels education is not a primary need (Yulistiono and Hapsari, 2019). According to Hanafi (1986), the level of education also determines whether or not someone easily absorbs information, generally the higher a person's education the better his understanding. Someone who has a higher education will have broader knowledge and insight, so they tend to be more open to new things and more quickly respond to changes that occur due to the application of an innovation.

The number of family dependents of $65 \%$ of the respondents is ranging from 3-4 people. As found by Prabayanti (2010), the number of family members will affect the family economy. The more the number of family members, the family needs will increase. This of course will also make the cost of living incurred even greater. However, if there are several people in a family who have an income the family income will increase.

Based on the experience of potato farming in Kanreapia Village, ranging from 7 - 19 years, as much as 20 people (50\%), 20-32 years with as much as 18 people $(45 \%)$. It is clearly indicated that almost all the respondents in Kanreapia village already has quite a long experience of farming, with this experience farmers tend to more easily absorb new things 
and innovate their farming activities. As the opinion expressed by Lubis (2000) that farmers who have long been engaged in farming will be easier to implement new technology than novice farmers. This is due to more experience, so that it can make comparisons in making decisions.

The majority of the respondents with $85 \%$ or 34 people have an average land area of cultivation between $0.2-1.4 \mathrm{Ha}$. Land area is closely related to the amount of production. The extent of farmland also allows farmers to maximize the level of production and quality of production. Farmers who have narrow land area tend to avoid risks. This is in accordance with the statement of Salikin (2003) that the factor affecting farmers in increasing farm productivity is the area of land worked on. The area of arable land also influences the speed of farmers to accept an innovation.

As many as 26 people or $65 \%$ are sharecropper farmers, and 14 others or $35 \%$ are owner farmers. As found by Theresia, et al. (2016) the main reason for farmers to rent land is because of the limited land they have so that in the end to be able to do their agricultural cultivation business, they are looking for rental land from other farmers.

\section{Factors Determining Farmers' Decisions in Partnering with Panenmart}

\section{Simultaneous Test (Omnibus Tests of Model Coefficient)}

In logistic regression, all $\mathrm{X}$ variables are tested simultaneously (together) through the omnibus test of model coefficient. In this test all independent variables are tested together. This test aims to see whether the independent variables simultaneously determine the decision of farmers to partner with Panenmart. The basis for decision making is if the significance value is greater than 0.05 , then $\mathrm{H} 0$ is accepted. While if the significance value is less than 0.05 , then $\mathrm{H} 0$ is rejected. The following table presents the results of the omnibus test.

Table 2. Simultaneous Test of Variable $X$ on Potato Farmer's Decision in Kanreapia Village to Partner with Panenmart

\begin{tabular}{llccc}
\hline & & Chi-square & df & Sig. \\
\hline Step 1 & Step & 55.452 & 14 & 0.000 \\
& Block & 55.452 & 14 & 0.000 \\
& Model & 55.452 & 14 & 0.000 \\
\hline
\end{tabular}

Source: Author's Elaboration, 2020.

Table 2 presents the value of Chi-square, df and significant Omnibus. This omnibus test presents output results in research with a Chisquare value of 55.452 , then a Chi-square table is obtained 23.668 at df 14 and alpha 0.05 . Chi-

Faculty of Agriculture,

University of Muslim Indonesia square value $>$ Chi-square table states that the variable $X$ simultaneously influences the $Y$ variable. In other words it can be said that age, education, number of family dependents, farming experience, land area, land ownership status, capital assistance, market guarantees, higher income, technology guarantees, product quality, obtaining assistance from extension agents, joint institutions with other farmers, and assistance from the government simultaneously have a significant (significant) effect on the decision of potato farmers in Kanreapia Village to partner with Panenmart.

\section{Partial Test (Multiple Logistic Regression)}

The decision of farmers to sell their potato products to Panenmart instead of village-level middlemen is one of the factors farmers need to consider in their farming. Many things can be considered by the farmers before deciding this because the decision to be taken requires good and careful planning to predict the outcome of the partnership decision.

In this study, there are 2 factors that partially affect the respondent farmers in making the decision to partner with Panenmart, namely age and the involvement in farmer group institutions. There are fourteen $X$ variables measured and the results of the logistic regression analysis is as follows.

Table 3. Factors Determining Decision of Potato Farmers in Partnership with Panenmart in Kanreapia Village

\begin{tabular}{|c|c|c|c|}
\hline Variabel & B & Sig. & $\operatorname{Exp}(B)$ \\
\hline Constant & 133.864 & 0.999 & $1.37 \mathrm{E}+61$ \\
\hline Age (X1) & -0.902 & $0.086^{*}$ & 0.406 \\
\hline Education (X2) & 3.972 & 0.214 & 0.019 \\
\hline $\begin{array}{l}\text { Family dependants } \\
\text { (X3) }\end{array}$ & 2.531 & 0.320 & 12.570 \\
\hline $\begin{array}{c}\text { Farming } \\
\text { experience }(X 4)\end{array}$ & -0.073 & 0.805 & 0.929 \\
\hline Land area (X5) & 3.110 & 0.489 & 22.425 \\
\hline $\begin{array}{l}\text { Land ownership } \\
\text { (X6) }\end{array}$ & 5.105 & 0.144 & 164.907 \\
\hline $\begin{array}{l}\text { Capital assistance } \\
\text { (X7) }\end{array}$ & 1.773 & 0.352 & 0.170 \\
\hline $\begin{array}{c}\text { Market guarntee } \\
\text { (X8) }\end{array}$ & 2.967 & 0.185 & 0.051 \\
\hline Hgher income (X9) & 3.853 & 0.170 & 0.021 \\
\hline $\begin{array}{c}\text { Technology } \\
\text { guarantee (X10) }\end{array}$ & 16.792 & 0.999 & 0 \\
\hline $\begin{array}{l}\text { Product quality } \\
\qquad(\mathrm{X} 11)\end{array}$ & 14.074 & 1.000 & 1294473.42 \\
\hline
\end{tabular}




\section{Study of Income Comparison on Potato Farmers between Panenmart's Partner and Non-Partner}

\begin{tabular}{cccc}
$\begin{array}{c}\text { Extension service } \\
(\mathrm{X} 12)\end{array}$ & 3.334 & 1.000 & 0.036 \\
$\begin{array}{c}\text { Farmer group } \\
(\mathrm{X} 13)\end{array}$ & 0.950 & $0.095^{*}$ & 0.387 \\
$\begin{array}{c}\text { Government } \\
\text { assitant }(\mathrm{X} 14)\end{array}$ & 7.796 & 1.000 & 0 \\
\hline $\mathrm{N}$ & 40 & & \\
$\begin{array}{l}\text { Nagerkelke R } \\
\text { square }\end{array}$ & 0.83 & & \\
\hline Source: Author's Elaboration, 2020
\end{tabular}

Table 3 shows the results of the multiple logistic regression analysis to look at the factors that determine the decision of potato farmers in Kanreapia Village to partner with Panenmart. Nagelkerke $R$ square value of 0.83 indicates that the variable $X$ in this study has the ability to explain the $Y$ variable by $83 \%$ and beyond that explained by other variables not examined in this study. Variables that proved significant in determining farmers' decisions in partnering with Panenmart were age (X1) and the participation in farmers group (X13). A value of $B$ in the age variable which shows a negative number (0.902) means that the younger the age of the respondent, the more they tend to partner. The coefficient value of Exp (B) for age is -0.406 , which means that the younger the respondent's age, their tendency to partner with Panenmart is 0.406 times compared to farmers whose age is older.

The coefficient value $\operatorname{Exp}(B)$ for the participation in farmer group institutions which shows the value of 0.387 gives an interpretation that the more actively involved farmers in farmer group institutions, then they are 0.387 times more tend to partner with Panenmart compared to farmers who are not actively involved in farmers group.

\section{Production and Income of Potato Farms}

This study measures the differences in production and income of Panenmart partners and non-partner farmers. Before analyzing these differences, it is necessary to specify the revenue, farm costs, and income of potato farmers per planting season per hectare. Farming costs are the total costs incurred by farmers during farming activities. Costs include the costs of cultivating land, seeds, fertilizer and drug costs, labor costs, and equipment depreciation costs. More details can be seen in the following table.

Table 4. Production and Income of Panenmart's Partner and Non-Partner per Planting Season per Hectare

Faculty of Agriculture,

University of Muslim Indonesia

\begin{tabular}{llrr}
\hline & \multirow{2}{*}{ Description } & \multicolumn{1}{l}{ Partner } & Non-Partner \\
\cline { 3 - 4 } & \multicolumn{1}{c}{ Value (Rp) } & Value (Rp) \\
\hline A & Production/ha & $3,943 \mathrm{~kg}$ & \multicolumn{1}{c}{$4,027 \mathrm{~kg}$} \\
B & Revenue/ha & $31,641,667$ & $26,991,667$ \\
C & Costs & & \\
& Production facilities/ha & $53,722,577$ & $8,537,767$ \\
& Labour/ha & $1,611,929$ & 790,797 \\
& Tool depreciation/ha & 170,253 & 142,059 \\
D & Total Cost/ha & $10,010,254$ & $9,470,623$ \\
E & Income/ha (B-D) & $21,631,413$ & $17,521,044$ \\
\hline Source: Author's Elaboration, 2020. &
\end{tabular}

Table 4 presents the average production, revenue, cost, and income per hectare per growing season of potato farmers in Kanreapia Village. The yield for partner farmers is $3,943 \mathrm{~kg}$ / ha / planting season and 4,027 kg / ha / planting season for non-partner farmers. Revenue for partner farmers is Rp. 31,641,667 / ha / planting season while Rp. 26,991,667 / ha / planting season for non-partner farmers. This revenue difference is due to the selling price of potatoes. If sold to Panenmart, the price per $\mathrm{kg}$ is $\mathrm{Rp}$. 12,000 - Rp. 13,000, while if sell to other, the price range is only between Rp. 9,000 - Rp. 10,000 . From this it is clear that selling products to Panenmart is more profitable for farmers, but not all products can meet the potato tuber size requirements set by Panenmart. The benefits of the potato farmer partnership with Panenmart are more on the acquisition of higher prices but there is no visible difference in potato production between partner and non-partner farmers. Last is the income for farmers per planting season per hectare, which is Rp. 21,631,431 and Rp. $17,521,044$ for non-partner farmers.

\section{E. T-Test of Income Differences}

Analysis of the difference of income level between potato farmers in both groups in Kanreapia Village was using the Independent Sample t-Test. Independent Sample t-Test is a different group test that is not interconnected. The Independent Sample t-Test aims to determine the average difference of the two sample groups and then see whether the difference is significant or not. For more details can be seen in the following table.

Table 5. T-test on Panenmart's Partner and Non-Partner Farmers per Planting Season per Hectare in Kanreapia Village.

Variable Asymp. Sig, (2-tailed) Mean Difference


Source: Author's Elaboration, 2020

The results of the Independent Sample TTest analysis of. The results of the analysis of income per hectare per planting season show asymp value. sig (2-tailed) 0.186 is greater than the significance level of 0.05 . This means that there is no significant difference between the income of partner and non-partner farmers, where the average income difference between the two groups is Rp. 4,110,369 per planting season per hectare. Thus, through a partnership carried out by potato farmers in Kanreapia Village, Gowa Regency does not bring significant increase in income compared to farmers who are not partnering even though the income of partner farmers remains higher than non-partner farmers. These results indicate that there is no significant economic benefit obtained by partner farmers because the difference in income is that revenue minus production costs is not too large. The price difference given by Panenmart to partner farmers is compared to the price given by traders at village level, which is only around $\mathrm{Rp}$. 2,000,-. This can also be related to the membership of farmers in institutions (farmer groups) because it is in accordance with the results of research by Fischer and Qaim (2012) who found that group membership leads to an increase in household income, but only for farmers who also market collectively. This underlines that it is not group membership that is important in benefiting partnerships between companies and farmers, but the participation of members in the group. As stated by Rankin, et al., (2016), although the income difference is not significant but through partnerships, farmers and companies can get the benefit of sharing the risk. Partnership not only bring income benefit to the farmers but also to the company.

\section{Conclusions}

Based on the results and discussion, the conclusions of this study are as follows:

1. Factors that determine the decision of potato farmers in Kanreapia Village to partner with Panenmart are the age and participation in farmers group.

2. There is no significant income difference between Panenmart's partners and nonpartners in Kanreapia Village.

\section{References}

Cahyarubin. (2016). Analisis Pendapatan Usahatani Tebu Petani Mitra Dan Non Mitra Pg Rejoagung Baru, Kabupaten Madiun. Sebuah Skripsi pada Fakultas Ekonomi dan Manajemen, Institut
Pertanian Bogor.

Fischer $E$ and Matin Qaim. 2012. Linking Smallholders to Markets: Determinants and Impacts of Farmer Collective Action in Kenya. Journal of World Development, Vol. 40, No. 6, pp. 12551268, 2012.

Hafsah, (2003). Kemitraaan Usaha. Jakarta: Pustaka Sinar Harapan.

Hanafi A. 1986. Memasyarakatkan Ide-ide Baru. (terjemahan) dari Rogers dan Shoemaker; Communication of Innovation. Surabaya: Usaha Nasional.

Harlan, J. (2018). Analisis Regresi Logistik. Penerbit Gunadarma.

Lubis, N, L. (2000). Adopsi Teknologi dan Faktor yang Memengaruhinya. USU Press. Medan.

Prabayanti, Herning. (2010). Faktor-faktor yang Mempengaruhi Adopsi Biopestisida oleh Petani di Kecamatan Mojogedang, Kabupaten Karanganyar. Skripsi pada Fakultas Pertanian, Universitas Sebelas Maret. Surakarta.

Rankin, M., E. G. Nogales, P. Santacoloma, N. Mhlanga, and C. Rizzo. (2016). PublicPrivate Partnerships for Agribusiness Development, A Review of International Experiences. Food and Agriculture Organization (FAO) of the United Nations.

Saifuddin, A., Notodiputro, K.A., Alamudi, A., Sadik, K. (2009). Statistika Dasar. Grasindo. Jakarta.

Salikin, Karwan. (2003). Sisitem Pertanian Berkelanjutan. Yogyakarta: Penerbit Kanisius. Jakarta: PT. Grasindo.

Soekartawi. 1988. Prinsip Dasar Komunikasi Pertanian. Jakarta: UI-Press.

Susanti, Kusnadi, N., Rachmina, D. (2016). Pengaruh Kemitraan Terhadap Produksi dan Pendapatan Usahatani Sayuran di Kabupaten Bogor. Sebuah tesis pada Fakultas Ekonomi dan Manajemen, Institut Pertanian Bogor.

Theresia, V., Anna Fariyanti, dan Netti Tinaprilla. (2016). Pengambilan Keputusan Petani Terhadap Penggunaan Benih Bawang Merah Lokal dan Impor di Cirebon, Jawa Barat. Jurnal AGRARIS, Vol. 2 No. 1 Januari 2016.

Yulistiono, F., and T. D. Hapsari. (2019). FaktorFaktor yang Mempengaruhi Keputusan Petani Bermitra dengan PT. Sirtanio Organik Indonesia. SEPA : Vol. 16 No.1 
Study of Income Comparison on Potato Farmers between Panenmart's Partner and Non-Partner

September $2019: 20-27$. 